Dissertações e teses - Resumos

\title{
A sombra da mãe: um estudo psicanalítico sobre identificação feminina a partir de casos de Vara de Família*
}

\author{
The mother's shadow: a psychoanalytical study of \\ feminine identification, based on family-court cases
}

\author{
Cláudia Amaral Mello Suannes ${ }^{1}$
}

Suannes, CAM. A sombra da mãe: um estudo psicanalítico sobre identificação feminina a partir de casos de Vara de Família. Saúde, Ética \& Justiça. 2008;13(2)104-5

Resumo: Esta pesquisa pretende traçar uma articulação entre feminilidade, maternidade e identificação a partir do atendimento - na condição de psicóloga perita de Vara de Família - de casos de disputa pela guarda de filhos. Trata-se de uma pesquisa qualitativa, sob o ângulo da Psicanálise. Tendo em vista que se desenvolveu em um setting particular, foi organizada em torno de dois eixos. No primeiro, apresenta-se o contexto institucional; indicam-se quais são os casos atendidos nas Varas de Infância e Juventude e nas de Família e Sucessões, e se aborda a atuação do psicólogo neste tipo de caso. Partindo da premissa que as ações das Varas de Família são travadas entre pessoas que mantêm entre si vínculos carregados de afetividade, problematiza-se o modelo pericial e se propõe uma escuta analítica que contenha em seu bojo uma possibilidade de intervenção (e, conseqüentemente, de pesquisa psicanalítica) junto a famílias que procuraram o Judiciário para resolver conflitos intrapsíquicos ou intersubjetivos. No segundo eixo, a partir da discussão de três casos, estabelece-se uma articulação entre feminilidade, maternidade e identificação. São casos nos quais as mulheres vivem o fato de a guarda provisória ter sido atribuída ao pai como uma perda narcísica, e a referência à alteridade da criança surge em segundo plano. Sem pretender generalizar, indaga-se sobre 0 valor narcísico da maternidade e sobre suas relações com a feminilidade. O vértice escolhido é a identificação dessas mulheres com suas próprias mães, notadamente quando esta opera ao modo de uma identificação melancólica.

Descritores: Família/psicologia. Mães/psicologia. Comportamento materno/psicologia. Identificação (psicologia). Psicologia/legislação \& jurisprudência. Psicanálise.

\footnotetext{
* Dissertação de mestrado - Pontifícia Universidade Católica de São Paulo. Mestrado em Psicologia Clínica. Orientador: Prof. Dr. Renato Mezan. São Paulo, 2008.

1 Psicóloga e Psicanalista, professora do curso de Psicologia Jurídica do Instituto Sedes Sapientiae. Especialista em Psicologia Jurídica pelo CFP e mestre em Psicologia Clínica pela PUC-SP.

Endereço PARA Correspondência: Cláudia Amaral Mello Suannes. Av. Brigadeiro Faria Lima, 1811, cj 1325. São Paulo, SP. 01451-914 E-mail: clausuannes@ terra.com.br
} 
Suannes, CAM. The mother's shadow: a psychoanalytical study of feminine identification, based on family-court cases. Dissertação (mestrado)- Pontifícia Universidade Católica de São Paulo. Mestrado em Psicologia Clínica. Orientador: Prof. Dr. Renato Mezan . São Paulo, 2008. Saúde, Ética \& Justiça. 2008;13(2):104-5. [Abstract]

Abstract: This study intends to trace out the connections among femininity, maternity and identification through the forensic psychologist's task in family courts, in cases that involve child-custody disputes. This is a qualitative study, with a psychoanalytic basis. The dissertation was developed in a particular setting and is organized around two main focuses. In the first one, there is the institutional context. Here are presented which are the cases under evaluation by the Child and Youth Court and the Family Court, as well as the description of the task of the psychologist in those processes. Starting with the premise that Family Court cases concern parties who maintain emotional connections with each other, the study questions the forensic model. It affirms the possibility of an psycoanalytical listening that also contains the possibility of intervention (and consequently of psychoanalytical research) into the families that seek the courts to resolve intrapsychic or intersubjective conflicts. The second focus is directed to articulate femininity, maternity and identification from the exam of three cases. In these, the women are faced with the fact that provisory custody is given to the father, thus making them feel it like a narcissist loss and the alterity of the child is kept in secondary place. Without intending to generalize, inquiryis made into the narcissistic value of maternity and its relationship to femininity, discussing the question with a focus on identification of these women with their own mothers, outstanding an identification that operates in the mode of melancholic identification.

KeYwords: Family/psychology. Mothers/psychology. Maternal behavior/psychology. Psychology/legislation \& jurisprudence. Identification (psychology). Psychoanalysis. 